\title{
ADOBE FLASH CS6 DALAM MENGHITUNG LUAS DAN KELILING BANGUN DATAR PADA DISKALKULIA
}

\author{
Sella Malinda ${ }^{1}$, Mega Iswari ${ }^{2}$, Jon Efendi ${ }^{3}$ \\ ${ }^{123}$ Universitas Negeri Padang, Indonesia \\ Email: sellamalinda.ak1@gmail.com
}

INFORMASI ARTIKEL

Terkirim 24 Februari 2018

Revisi 27 Juli 2019

Diterima 05 April 2020

Kata kunci:

adobe flash CS6, diskalkulia

\begin{abstract}
ABSTRAK
Penelitian ini di latarbelakangi oleh permasalahan yang tampak di lapangan, yaitu anak diskalkulia di kelas V SDN 08 Surau Gadang Padang yang mengalami permasalahan dalam matematika mengenai materi menghitung luas dan keliling bangun datar. Penelitian ini menggunakan quasi experimental design dengan jenis one group pretest-posttest design. Hasil penelitian ini diperoleh berdasarkan analisis data yang dilihat dari skor pretest dan posttest. Data diolah menggunakan uji mann whitney. Diketahui $\mathrm{n}_{1}=5$ dan $\mathrm{n}_{2}=5$ pada taraf signifikan $95 \%$ dan $\alpha=$ 0,05 diperoleh $\mathrm{U}_{\text {hit }}=0$ dan $\mathrm{U}_{\mathrm{tab}}=4$. Hipotesis nol diterima karena $\mathrm{U}_{\text {hit }} \leq \mathrm{U}_{\text {tab. Jadi, }}$. penggunaan media pembelajaran berbasis adobe flash CS6 tidak efektif dalam meningkatkan kemampuan menghitung luas dan keliling bangun datar pada anak diskalkulia di kelas V SDN 08 Surau Gadang Padang.
\end{abstract}

This is an open access article distributed under the Creative Commons 4.0 Attribution License, This license lets others remix, tweak, and build upon your work even for commercial purposes, as long as they credit you and license their new creations under the identical terms $\odot 2018$ by author and Universitas Negeri Padang.

Pendahuluan

Matematika adalah mata pelajaran yang memegang peranan penting dalam pendidikan dikarenakan mata pelajaran matematika dapat diterapkan dalam kehidupan sehari-hari. Salah satu kemampuan dalam bidang matematika ialah kemampuan dalam memahami berbagai bentuk dan struktur di dalam lingkungan yang sangat berkaitan dengan geometri, kemampuan mengukur, dan menumbuh kembangkan dalam memecahkan masalah matematika dalam kehidupan sehari-hari (Jamaris, 2009:247). Membangun pemahaman konsep luas dan keliling pada bangun datar peersegi, persegi panjang, dan segitiga tidaklah mudah bagi siswa Sekolah Dasar (SD) (Fitriyanti, Lukito, \& Eko, 2016). Kemampuan memahami bentuk geometri yang harus diajarkan kepada anak terlebih dahulu ialah memperkenalkan konsep geometri yang sederhana atau bangun datar seperti persegi mempunyai empat sisi, lingkaran tidak mempunyai sisi, dan segitiga mempunyai tiga sisi. Tahap selanjutnya, anak dapat menentukan bentuk dan menyelesaikan permasalahan dalam menghitung luas dan keliling bangun datar. Kemampuan tersebut bertujuan untuk melatih kognitif dan persepsi visual anak serta mengembangkan kemampuan matematikanya, tetapi tidak bagi anak yang mengalami kesulitan belajar matematika (diskalkulia).

Kesulitan belajar matematika memiliki ciri-ciri yang berbeda dibandingkan dengan kesulitan belajar dalam mata pelajaran yang lainnya (Untari, 2013). Bagi seorang guru istilah diskalkulia digunakan dikarenakan anak memperoleh hasil belajar matematika yang rendah dibandingkan dengan teman sebayanya. Hasil belajar berhitung rendah dikarenakan anak belum mampu memahami konsep matematika dan memecahkan soal matematika (Yusuf, 2005:206).

Anak berkesulitan belajar matematika akan mengalami ketidakpahaman dalam memahami menghitung luas dan keliling bangun datar, karena kegiatan pembelajaran tersebut mendorong anak untuk melakukan pengamatan dalam menentukan nilai panjang, lebar, alas, dan tinggi serta memecahkan masalah yang berkaitan dengan luas dan keliling bangun datar. Dampak yang akan ditimbulkan jika anak tidak mampu memahami cara menghitung luas dan keliling bangun datar, maka anak akan merasa sulit menghubungkan konsep-konsep menghitung luas dan keliling bangun datar dengan kenyataan yang ada, misalnya mencari luas meja, mencari luas tanah, mencari keliling ruang tamu, dll.

Berdasarkan studi pendahuluan yang penulis lakukan di SDN 08 Surau Gadang Padang pada kelas V-B, bahwasannya terdapat dua puluh lima siswa/i yang duduk di kelas tersebut. Penulis mengamati proses pembelajaran dalam menghitung luas dan keliling bangun datar, terlihat anak tampak bosan saat mengikuti pembelajaran tersebut dikarenakan guru menggunakan metode ceramah, demonstrasi, dan penugasan serta media yang digunakan hanya menggunakan papan tulis untuk menjelaskan cara penyelesaian menghitung luas dan keliling bangun datar.

Berdasarkan observasi yang diperoleh bahwa anak sudah mampu memahami bentuk dari bangun datar persegi, persegi panjang, dan segitiga, tetapi saat menghitung luas dan keliling bangun datar ada lima anak yang masih tampak

Open Acces Jurnal: http://jpkk.ppj.unp.ac.id 
bingung, yakni AP, FRJ, IF, AJ, dan AM. Anak sering menyelesaikan soal menghitung luas dan keliling bangun datar dengan memasukkan angka tanpa mengetahui makna dari angka tersebut. Hal ini dibuktikan dengan hasil belajar anak serta tes mengenai bangun datar yang terdiri dari menyebutkan jenis bentuk bangun datar, serta menghitung luas dan keliling bangun datar yang diberikan oleh penulis. Penulis menggunakan pedoman instrumen Hellen Keller Internasional (HKI) yang dimodifikasi kelas IV semester I dan kelas III semester II untuk memberikan tes kepada lima anak tersebut.

Pernyataan tersebut didukung juga dari informasi guru. Dari hasil wawancara dengan guru, bahwasannya AP, FRJ, IF, AJ, dan AM mengalami masalah dengan mata pelajaran matematika. Nilai rata-rata hasil matematika yang diperoleh anak masih di bawah Kriteria Ketuntasan Minimal (KKM) matematika yang ditetapkan di sekolah yaitu 75,00. Kurikulum yang digunakan untuk pelajaran matematika masih menggunakan KTSP 2006. Dari informasi tersebut, dapat dikatakan bahwa AP, FRJ, IF, AJ, dan AM sangat membutuhkan perhatian khusus untuk menangani permasalahannya dalam belajar.

Berdasarkan hasil pengamatan dan wawancara yang telah dilakukan, selanjutnya penulis melakukan asesmen tentang menghitung luas dan keliling bangun datar terhadap kelima anak tersebut. Dari sepuluh soal bangun datar yang diberikan, hanya satu anak saja yang memperoleh $15 \%$ dari $100 \%$, keempat anak lainnya memperoleh skor $0 \%$. Penilaian dilakukan dengan cara skor yang diperoleh anak dibandingkan dengan skor maksimal kemudian dikalikan dengan $100 \%$.

Dengan permasalahan pada kemampuan menghitung luas dan keliling bangun datar, anak akan mengalami kesulitan saat belajar mengenai materi menghitung volume bangun ruang yaitu lanjutan materi mengenai geometri, karena materi mengenai menghitung luas dan keliling bangun datar anak tidak memahaminya. Untuk membantu anak dalam pembelajaran mengenai menghitung luas dan keliling bangun datar, maka digunakan media pembelajaran yang menarik untuk menunjang pemahaman anak mengenai pembelajaran menghitung luas dan keliling bangun datar. Salah satunya ialah media pembelajaran yang memanfaatkan aplikasi adobe flash CS6. Adobe flash CS6 adalah salah satu perangkat lunak komputer yang merupakan produk terbaru dari adobe systems. Adobe flash CS6 digunakan untuk membuat program yang berisikan gambar vektor maupun animasi gambar, serta dapat mengembangkan menjadi program yang menarik (Haryawan, 2014). Dimana aplikasi adobe flash CS6 dapat mempermudah programmer dalam membuat animasi dan hasilnya lebih baik, dan banyak diminati programmer dikarenakan kehandalannya yang dapat membantu programmer dalam membuat segala hal yang berkaitan untuk pembuatan game, media pembelajaran, web site, film kartun, dan sebagainya (Haryawan, 2014). Media pembelajaran berbasis adobe flash CS6 ini dapat menarik perhatian anak dan dapat secara langsung digunakan oleh anak dengan mudah karena sudah terprogram, di mana dalam media pembelajaran tersebut terdapat materi menghitung luas dan keliling bangun datar yang terdiri dari luas dan keliling persegi, persegi panjang, dan segitiga, beserta latihan dari masing-masing jenis bangun datar.

Program yang dirancang akan memunculkan musik yang bertujuan untuk membuat suasana yang menyenangkan, serta animasi yang bertujuan untuk memberikan makna bahwasannya yang bergerak tersebut adalah sisi panjang, lebar, alas, dan tinggi suatu bangun datar, dan terdapat teks di dalam materi, serta terdapat hyperlink yang bertujuan untuk mempermudah penggunaan media. Berangkat dari masalah tersebut, maka artikel ini membahas tentang permasalahan dalam menghitung luas dan keliling bangun datar yang dibantu dengan menggunakan media pembelajaran berbasis adobe flash CS6.

\section{Metode}

Penelitian ini menggunakan quasi experimental design dengan jenis one group pretest-posttest design. Menurut Nazir (2013:205) menyatakan bahwa "di dalam desain ini dikenakan perlakuan dengan dua kali pengukuran. Pengukuran pertama dilakukan sebelum perlakuan diberikan, dan pengukuran kedua dilakukan sesudah perlakuan dilaksanakan.”

Teknik analisis data yang digunakan adalah statistik non parametrik, karena subjek penelitian sebanyak lima orang anak yang mengalami diskalkulia. Dikarenakan penelitian ini bersifat komparasi, subjek yang digunakan kurang dari tiga puluh, serta data bersifat ordinal, maka digunakanlah uji mann whitney. Menurut Nazir (2013: 355) mengemukakan bahwa uji mann whitney merupakan "alternatif lain untuk menguji beda mean dari dua sampel".

\section{Hasil Penelitian dan Pembahasan \\ Hasil Penelitian}

Setelah mendapatkan skor di hasil pretest dan posttest, tahap selanjutnya ialah menentukan rank dari masingmsing subjek penelitian sebelum diberikan perlakuan $\left(\mathrm{T}_{0}\right)$ dan setelah diberikan perlakuan $\left(\mathrm{T}_{1}\right)$ untuk dianalisis dengan menggunakan rumus uji mann whitney. Adapun hasil pretest dan posttest yang diperoleh terhadap kemampuan menghitung luas dan keliling bangun datar pada anak diskalkulia. 
Tabel 1. Skor Pretest dan Posttest dalam Menghitung Luas dan Keliling Bangun Datar Kelas V di SDN 08 Surau Gadang Padang

\begin{tabular}{cccc}
\hline No & Subjek Penelitian & Skor Pretest & Skor Posttest \\
\hline 1. & AP & 32,9 & 85,7 \\
\hline 2. & FRJ & 17,1 & 75,7 \\
\hline 3. & IF & 1,4 & 85,7 \\
\hline 4. & AJ & 7,1 & 77,1 \\
\hline 5. & AM & 1,4 & 58,5 \\
\hline & Rata-rata & $\mathbf{1 1 , 9 8}$ & $\mathbf{7 6 , 5 4}$ \\
\hline
\end{tabular}

Adapun hasil rank dari skor pretest dan posttest dalam kemampuan menghitung luas dan keliling bangun datar, sebagai berikut:

Tabel 2. Data Persiapan Menghitung Rank Anak Dalam Kemampuan Menghitung Luas dan Keliling Bangun Datar di Kelas V SDN 08 Surau Gadang Padang

\begin{tabular}{cccc}
\hline No. & Subjek Penelitian & Nilai Skor & Rank \\
\hline 1. & AP & 85,7 & 1,5 \\
\hline 2. & IF & 85,7 & 1,5 \\
\hline 3. & AJ & 77,1 & 3 \\
\hline 4. & FRJ & 75,7 & 4 \\
\hline 5. & AM & 58,5 & 5 \\
\hline 6. & AP & 32,9 & 6 \\
\hline 7. & FRJ & 17,1 & 7 \\
\hline 8. & AJ & 7,1 & 8 \\
\hline 9. & AM & 1,4 & 9,5 \\
\hline 10. & IF & 1,4 & 9,5
\end{tabular}

Setelah melakukan pengolahan data, maka diperoleh angka yang digunakan untuk menghitung dengan menggunakan rumus uji mann whitney. Berdasarkan hasil perhitungan, maka diperoleh $\mathrm{U}_{\mathrm{hit}}=0$ yang diambil berdasarkan nilai hitung terkecil. Kemudian disesuaikan pada taraf signifikan $95 \%$ dan $\alpha=0,05$ untuk $\mathrm{n}_{1}=5$ dan $\mathrm{n}_{2}=5$ diperoleh $\mathrm{U}_{\text {tab }}=$ 4 yang diambil dari tabel uji mann whitney pada satu ekor.

Menurut Nazir (2013:357) titik tolak dari uji mann whitney dalam membedakan dua mean adalah "jika rank dari sebuah sampel berkelompok dalam satu ujung distribusi, sedangkan rank-rank dari sampel yang satu lagi berkelompok pada ujung distribusi yang lain, maka U akan menjadi nol". Dengan perkataan lain, jika U = 0, terdapat kemungkinan perbedaan yang paling besar antara kedua sampel tersebut. Nilai U akan menjadi besar jika rank bercampur antara satu kelompok dengan kelompok yang lain.

Berdasarkan perhitungan menggunakan uji mann whitney, hal ini menunjukkan bahwa media pembelajaran berbasis adobe flash CS6 tidak efektif untuk meningkatkan kemampuan menghitung luas dan keliling bangun datar pada anak diskalkulia kelas V di SDN 08 Surau Gadang Padang.

\section{Pembahasan}

Penelitian yang dilakukan menggunakan media pembelajaran berbasis adobe flash CS6 dalam meningkatkan kemampuan menghitung luas dan keliling bangun datar pada diskalkulia. Berdasarkan pengamatan penulis, anak tampak bersemangat dan antusias belajar menggunakan media pembelajaran berbasis adobe flash CS6 dikarenakan media tersebut sangat menarik dan mudah dipergunakan oleh anak. Penggunaan media pembelajaran berbasis adobe flash CS6 dapat memberikan pengaruh positif terhadap motivasi dan prestasi belajar anak meningkat (Haryawan, 2014).

Berdasarkan data yang telah diperoleh dapat terlihat bahwa sebelum diberikan media pembelajaran berbasis adobe flash CS6 (pretest) terhadap kemampuan anak dalam menghitung luas dan keliling memperoleh skor rendah dibandingkan setelah diberikan media pembelajaran berbasis adobe flash CS6 (postest). Setelah data di analisis menggunakan uji mann whitney, maka hasil uji hipotesis dapat dikatakan bahwa penggunaan media pembelajaran berbasis adobe flash CS6 tidak efektif untuk meningkatkan kemampuan anak dalam menghitung luas dan keliling bangun datar. Hasil uji hipotesis dengan menggunakan uji mann whitney bertolabelakang dengan perolehan skor pretest dan posttest terhadap kelima anak 
diskalkulia. Tetapi penulis tidak terfokus pada hasil uji hipotesis menggunakan uji mann whitney, melainkan fokus terhadap perbandingan hasil yang meningkat antara skor pretest dengan skor posttest yang diperoleh anak.

Penelitian yang menggunakan media pembelajaran berbasis adobe flash CS6 pernah dilakukan sebelumnya oleh Agus Haryawan (2014:71) yang berjudul "Pengembangan Media Pembelajaran Berbasis Adobe Flash CS6 Untuk Meningkatkan Motivasi dan Prestasi Belajar Mata Kuliah Pemrograman Bahasa Rakitan di Politama Surakarta”. Pada penelitian ini menunjukkan bahwa rata-rata nilai posttest kelas eksperimen lebih tinggi dibandingkan rata-rata nilai posttest kelas kontrol, dan terjadinya pengaruh yang positif pada motivasi dan prestasi belajar mahasiswa. Selanjutnya penelitian dari Yeni R. Saselah (2017:87) yang berjudul "Pengembangan Multimedia Interaktif Berbasis Adobe Flash CS6 Professional Pada Pembelajaran Kesetimbangan Kimia”. Pada penelitian ini dikatakan bahwasannya multimedia yang dihasilkan sangat layak digunakan dalam pembelajaran baik di dalam kelas maupun belajar sendiri.

\section{Kesimpulan}

Berdasarkan pengujian hipotesis dengan menggunakan uji statistik mann whitney, dapat disimpulkan bahwasannya penggunaan media pembelajaran berbasis adobe flash CS6 tidak efektif dalam meningkatkan kemampuan menghitung luas dan keliling bangun datar pada anak diskalkulia. Tetapi, berdasarkan skor pretest dan posttest yang diperoleh anak bahwasannya media pembelajaran berbasis adobe flash CS6 efektif digunakan untuk menunjang kemampuan menghitung luas dan keliling bangun datar pada anak diskalkulia.

Daftar Rujukan

Fitriyanti, I.R., Lukito, A., \& Siswono, T.Y.E. (2016). Pengembangan Perangkat Pembelajaran Matematika Realistik Topik Luas dan Keliling Bangun Datar Kelas III Sekolah Dasar. Jurnal Review Pendidikan Dasar, 3 (2), hlm. 305.

Haryawan, A. (2014). Pengembangan Media Pembelajaran Berbasis Adobe Flash CS^ Untuk Meningkatkan Motivasi dan Prestasi Belajar Mata Kuliah Pemrogaman Bahasa Rakitan di Politama Surakarta. Politeknosains, 1 (XIII), hlm. 64.

Jamaris, M. (2009). Kesulitan Belajar Perspektif: Assessmen dan Penanggulangannya. Jakarta: Yayasan Penamas Murni.

Nazir, M. (2013). Metode Penelitian. Bogor: Penerbit Ghalia Indonesia.

Untari, E. (2013). Diagnosis Kesulitan Belajar Pokok Bahasan Pecahan Pada Siswa Kelas V Sekolah Dasar. Jurnal Ilmiah STKIP PGRI Ngawi, 1 (13), hlm. 2.

Saselah, Y.R., Amir, M.M., \& Qadar, R. (2017). Pengembangan Multimedia Interaktif Berbasis Adobe Flash CS6 Professional Pada Pembelajaran Kesetimbangan Kimia. Jurnal Kimia dan Pendidikan Kimia, 2 (2), hlm. 87.

Yusuf, M. (2005). Pendidikan Bagi Anak Dengan Problema Belajar. Jakarta: Departemen Pendidikan Nasional Direktorat Jenderal Pendidikan Tinggi Direktorat Pembinaan Pendidikan Tenaga Kependidikan Dan Ketenagaan Perguruan Tinggi. 